Article

\title{
Alternative Approach to Current EU BAT Recommendation for Coal-Fired Power Plant Flue Gas Desulfurization Wastewater Treatment
}

\author{
Jan Bogacki * (D), Piotr Marcinowski ${ }^{\mathbb{D}}$, Maciej Majewski, Jarosław Zawadzki and \\ Sridhar Sivakumar
}

Faculty of Building Services, Hydro and Environmental Engineering, Warsaw University of Technology, 00-653 Warszawa, Poland; piotr.marcinowski@pw.edu.pl (P.M.); maciej.majewski@enea.pl (M.M.); j.j.zawadzki@gmail.com (J.Z.); sridharenviro03@gmail.com (S.S.)

* Correspondence: jan.bogacki@pw.edu.pl; Tel.: +48-22-234-5423

Received: 18 October 2018; Accepted: 14 November 2018; Published: 19 November 2018

\begin{abstract}
Fossil fuel combustion is a serious environmental problem. Significant quantities of flue gasses and wastewater, requiring further treatment, are produced. This article compares three wet flue gas desulfurization (FGD) wastewater treatment methods: coagulation with precipitation using iron(III) ions-recommended by the European Union as the best available technique (BAT)—and two alternative advanced oxidation processes $\left(\mathrm{Fe}^{2+} / \mathrm{H}_{2} \mathrm{O}_{2}\right.$ and $\left.\mathrm{Fe}^{0} / \mathrm{H}_{2} \mathrm{O}_{2}\right)$. Both oxidation processes that were used met the technical FGD wastewater treatment requirements of the BAT. The best treatment effects, expressed as pollutants' removal, were obtained for the $\mathrm{Fe}^{2+} / \mathrm{H}_{2} \mathrm{O}_{2}$ process for $150 / 300 \mathrm{mg} / \mathrm{L}$ reagent doses. It allows effective removal of boron up to $212 \mathrm{mg} / \mathrm{L}$ and heavy metals up to below the detection limit $<0.010 \mathrm{mg} / \mathrm{L}$ for $\mathrm{Pb}$ and $<0.005 \mathrm{mg} / \mathrm{L}$ for $\mathrm{Cu}$. Therefore, the $\mathrm{Fe}^{2+} / \mathrm{H}_{2} \mathrm{O}_{2}$ process could be an option for FGD wastewater treatment as an alternative to the BAT recommended iron(III)-based coagulation with precipitation. Additionally, an analysis of variance was applied to check the significance of the two independent variables and their interactions. Statistical analysis confirmed high efficiency and applicability of treatment process.
\end{abstract}

Keywords: wastewater treatment; heavy metals; Fenton process; ZVI; flue gas desulfurization wastewater

\section{Introduction}

Coal combusted in power plants is the main source of energy in Poland. As a by-product, considerable quantities of solid waste, ash, and flue gases are generated. Flue gas purification consists of the removal of solid particles, nitrogen oxides, and sulfur oxides. As a result of desulphurization, where the most commonly used method is wet lime [1-8], a significant amount of wastewater is generated.

Wastewater from the wet flue gas desulphurization (FGD) system is characterized by a high content of inorganic compounds in the form of salts, primarily gypsum $[9,10]$. Salinity can be above 20,000 $\mathrm{mg} / \mathrm{L}$ chlorides and $2000 \mathrm{mg} / \mathrm{L}$ sulfates(VI). In addition, heavy metals and organic compounds are also present in wastewater. The main factors influencing the quality and quantity of wastewater generated are the parameters of the coal, combustion, and the FGD system hydraulic load.

For the treatment of FGD wastewater, various methods have been used, including coagulation [3,9-13], filtration [3,10], alkalization for hydroxide precipitation [3,10], sedimentation [3,10], adsorption on gypsum [14] or ferrate(VI) [15], $\mathrm{Fe}^{0}$ usage [6], $\mathrm{Fe}^{0} / \mathrm{H}_{2} \mathrm{O}_{2}$ process [16], and pollutants' complexation [17]. However, these methods do not effectively reduce the high salinity of wastewater. Effective FGD wastewater desalination can be carried out using membrane or evaporative technologies, 
but the complex composition of the matrix makes such technologies difficult to apply and not economically viable.

Furthermore, FGD wastewater must be treated in a manner consistent with the best available technique (BAT) in large combustion plants [18], Polish legal regulations, and integrated water permits obtained by the system power plant.

Based on the BAT, the most common wastewater treatment technology uses dual iron salt coagulation, initially at $\mathrm{pH} 6.0$ and then at 8.5 , performed simultaneouslywith the complexation of heavy metals with the use of TMT-15 (15\% aqueous solution of an organic sulfide, trisodium 1,3,5-triazine-2,4,6-trithiolate). The use of such treatment technology may be insufficient to meet legal requirements. As such, there is a need to search for more efficient FGD wastewater treatment methods.

Advanced oxidation processes (AOP), such as the Fenton process, are promising unconventional treatment methods for wastewater containing concentrated and potentially toxic compounds. AOP methods consist of the efficient production of free radicals (primarily $\mathrm{HO}^{\bullet}$ ) that effectively oxidize pollutants contained in the wastewater.

In the heterogenic Fenton process $\left(\mathrm{Fe}^{0} / \mathrm{H}_{2} \mathrm{O}_{2}\right.$ process), metallic iron $\left(\mathrm{Fe}^{0}\right.$, zero-valent iron, $\left.\mathrm{ZVI}\right)$ in acidic conditions is an $\mathrm{Fe}^{2+}$ ion source. $\mathrm{Fe}^{2+}$ ions in the presence of $\mathrm{H}_{2} \mathrm{O}_{2}$ undergo oxidation to $\mathrm{Fe}^{3+}$, while $\mathrm{H}_{2} \mathrm{O}_{2}$ undergoes conversion to $\mathrm{HO}^{\bullet}$ and $\mathrm{OH}^{-}$, as in the classical homogeneous Fenton process. Adding $\mathrm{Fe}^{0}$ into the aqueous phase starts two catalytic mechanisms. The first one is heterogenic catalysis, related tothe presence of dispersed $\mathrm{Fe}^{0}$ phase. On the solids' surface, numerous processes take place, including oxidation and reduction of pollutants and catalysts, precipitation and co-precipitation of metal oxides and hydroxides, adsorption, and coagulation. Reactions (1)-(5) allow for divalent iron ion reactions, while reactions (6)-(10) describes Fenton process chemistry.

$$
\begin{gathered}
\mathrm{Fe}^{0}+\mathrm{O}_{2}+2 \mathrm{H}^{+} \rightarrow \mathrm{Fe}^{2+}+\mathrm{H}_{2} \mathrm{O}_{2} \\
\mathrm{Fe}^{0}+2 \mathrm{H}^{+} \rightarrow \mathrm{Fe}^{2+}+\mathrm{H}_{2} \\
\mathrm{Fe}^{0}+2 \mathrm{Fe}^{3+} \rightarrow 3 \mathrm{Fe}^{2+} \\
\mathrm{Fe}^{0}+\mathrm{H}_{2} \mathrm{O}_{2}+2 \mathrm{H}^{+} \rightarrow \mathrm{Fe}^{2+}+2 \mathrm{H}_{2} \mathrm{O} \\
\mathrm{Fe}^{0} \rightarrow \mathrm{Fe}^{2+}+2 \mathrm{e} \\
\mathrm{Fe}^{2+}+\mathrm{H}_{2} \mathrm{O}_{2} \rightarrow \mathrm{Fe}^{3+}+\mathrm{HO}^{-}+\mathrm{HO}^{\bullet} \\
\mathrm{Fe}^{3+}+\mathrm{H}_{2} \mathrm{O}_{2} \rightarrow \mathrm{Fe}^{2+}+\mathrm{H}^{+}+\mathrm{HO}_{2} \\
\mathrm{Fe}^{2+}+\mathrm{HO}^{\bullet} \rightarrow \mathrm{Fe}^{3+}+\mathrm{HO}^{-} \\
\mathrm{Fe}^{2+}+\mathrm{HO}_{2}^{\bullet} \rightarrow \mathrm{Fe}^{3+}+\mathrm{HO}_{2}^{-} \\
\mathrm{Fe}^{3+}+\mathrm{HO}_{2} \rightarrow \mathrm{Fe}^{2+}+\mathrm{H}^{+}+\mathrm{O}_{2}
\end{gathered}
$$

AOPs, such as the Fenton process and its modifications, proved to be very effective in various wastewater treatments [19]. Metallic iron and other iron-based catalysts were used, interalia, for the treatment of pharmaceuticals [20,21], trinitrotoluene (TNT) wastewater [22], phenols and chlorophenols [23,24], pesticides [25], bisphenol A (BPA) [26], landfill leachate [27] or coking wastewater [28], palm oil mill effluent [29], nitrite reduction [30], oil sands reclamation [31], surfactant removal [32], and hydraulic fracturing flow back fluid treatment [33].

Of additional importance, homogenous and heterogeneous Fenton processes meet the technical FGD wastewater treatment requirements of the BAT for large combustion sources in terms of treatment unit processes applied [18]. As a result of wastewater treatment, significant total organic carbon (TOC), chemical oxygen demand (COD), total suspended solids (TSS), and heavy metals removal should be obtained. 
The research was carried out in cooperation with a Polish system power plant operator, with the intention of the BAT conclusions being implemented on an industrial scale. Therefore, the aim of this study was to assess the possibility of using homogenous and heterogeneous Fenton processes for the wet lime method of FGD wastewater treatment as an alternative for the BAT recommended iron-based double coagulation.

\section{Materials and Methods}

\subsection{Sample Collection}

Wastewater was collected from an FGD equalization tank in a power plant. After wastewater collection, samples were refrigerated at $4{ }^{\circ} \mathrm{C}$ until analysis. The determined parameters and determination methods are shown in Table 1. All experiments concerning the FGD wastewater treatment were conducted within $72 \mathrm{~h}$ of sample collection. The wastewater was subjected to the following processes: heterogeneous Fenton $\left(\mathrm{Fe}^{0} / \mathrm{H}_{2} \mathrm{O}_{2}\right)$, homogeneous Fenton $\left(\mathrm{Fe}^{2+} / \mathrm{H}_{2} \mathrm{O}_{2}\right)$, and coagulation with iron-based coagulants. All experiments were carried out in duplicate.

Table 1. Parameters determined in raw and sedimented FGD (flue gas desulphurization) wastewater and determination methods (COD: chemical oxygen demand; TOC: total organic carbon).

\begin{tabular}{cccc}
\hline Parameter & Unit & Raw & Sedimented \\
\hline $\mathrm{pH}$ & - & 6.74 & 6.7 \\
Conductivity & $\mathrm{mS} / \mathrm{cm}$ & 33.4 & 30.8 \\
$\mathrm{COD}$ & $\mathrm{mg} / \mathrm{L}$ & 395 & 301 \\
$\mathrm{TOC}$ & $\mathrm{mg} / \mathrm{L}$ & 47.81 & 43.57 \\
$\mathrm{Cl}^{-}$ & $\mathrm{mg} / \mathrm{L}$ & 12,242 & 11,168 \\
$\mathrm{SO}_{4}{ }^{2-}$ & $\mathrm{mg} / \mathrm{L}$ & 1722 & 1651 \\
$\mathrm{NO}_{3}{ }^{-}$ & $\mathrm{mg} / \mathrm{L}$ & 232 & 185 \\
$\mathrm{~B}$ & $\mathrm{mg} / \mathrm{L}$ & 340 & 336 \\
$\mathrm{Ag}$ & $\mathrm{mg} / \mathrm{L}$ & 0.039 & 0.028 \\
$\mathrm{Cr}$ & $\mathrm{mg} / \mathrm{L}$ & 0.447 & 0.026 \\
$\mathrm{Cu}$ & $\mathrm{mg} / \mathrm{L}$ & 0.610 & 0.059 \\
$\mathrm{Ni}$ & $\mathrm{mg} / \mathrm{L}$ & 1.226 & 0.606 \\
$\mathrm{~Pb}$ & $\mathrm{mg} / \mathrm{L}$ & 2.018 & 0.016 \\
$\mathrm{~V}$ & $\mathrm{mg} / \mathrm{L}$ & 1.489 & 0.042 \\
$\mathrm{Cd}$ & $\mathrm{mg} / \mathrm{L}$ & 0.308 & 0.308 \\
$\mathrm{Zn}$ & $\mathrm{mg} / \mathrm{L}$ & 15.9 & 14.3 \\
$\mathrm{Fe}$ & $\mathrm{mg} / \mathrm{L}$ & 129.6 & 0.840 \\
\hline
\end{tabular}

\subsection{Treatment Processes}

The $\mathrm{Fe}^{0}$ used in the experiments was supplied by Hepure (Hepure, Hillsborough, NJ, USA) as Ferox Target (325 mesh). All reagents used were analytical grade.

The $\mathrm{Fe}^{0} / \mathrm{H}_{2} \mathrm{O}_{2}$ process was carried out in a $1.5 \mathrm{~L}$ reactor filled with a $1 \mathrm{~L}$ sample. Solid Fe ${ }^{0}$ (Hepure, Hillsborough, NJ, USA) and $30 \% \mathrm{H}_{2} \mathrm{O}_{2}$ (Stanlab, Lublin, Poland) solution were used. Wastewater samples were stirred at $500 \mathrm{rpm}$ on a magnetic stirrer (Heidolph MR3000, Schwabach, Germany). The $\mathrm{pH}$ during the $\mathrm{Fe}^{0} / \mathrm{H}_{2} \mathrm{O}_{2}$ process was 3.0. After specified times (15, 30, and $60 \mathrm{~min}$ ), the $\mathrm{Fe}^{0} / \mathrm{H}_{2} \mathrm{O}_{2}$ process was stopped by increasing the $\mathrm{pH}$ to 8.5 using $3 \mathrm{M} \mathrm{NaOH}$ (Stanlab, Lublin, Poland). Samples were left overnight to allow hydrogen peroxide decomposition and iron-based sludge sedimentation.

The $\mathrm{Fe}^{2+} / \mathrm{H}_{2} \mathrm{O}_{2}$ process was carried out in a $1.5 \mathrm{~L}$ reactor filled with a $1 \mathrm{~L}$ sample. $\mathrm{Fe}^{2+}$ in a form of acidic $\mathrm{FeSO}_{4}$ (Stanlab, Lublin, Poland) $50 \mathrm{mg} \mathrm{Fe}{ }^{2+} / \mathrm{mL}$ solution (POCh, Gliwice, Poland) and 30\% $\mathrm{H}_{2} \mathrm{O}_{2}$ solution (Stanlab, Lublin, Poland) were used. Wastewater samples were stirred at $500 \mathrm{rpm}$ on a magnetic stirrer (Heidolph MR3000, Schwabach, Germany). The $\mathrm{pH}$ during the Fenton process was adjusted to 3.0 with $1 \mathrm{M} \mathrm{H}_{2} \mathrm{SO}_{4}$ (Stanlab, Lublin, Poland). After the specified times (5, 15, 30, and 
$60 \mathrm{~min}$ ), processes were stopped by increasing the $\mathrm{pH}$ to 8.5 using $3 \mathrm{M} \mathrm{NaOH}$. Samples were left overnight to allow hydrogen peroxide decomposition and iron-based sludge sedimentation.

Hydrogen peroxide process doses were selected according to sedimented wastewater COD in 0.5:1, 1:1, 2:1, 4:1, and 8:1 COD/ $\mathrm{H}_{2} \mathrm{O}_{2}$ mass ratios, while divalent iron doses were selected according to $1: 2,1: 4$, and $1: 4 \mathrm{Fe}^{2+} / \mathrm{H}_{2} \mathrm{O}_{2}$ mass ratios.

Coagulation was carried out in a $1.5 \mathrm{~L}$ reactor filled with $1 \mathrm{~L}$ of sample. Commercially available coagulant and TMT-15 solutions (Brenntag, Essen, Germany) were used. Anionic flocculent Flopam AN913SH (SNF, Andrézieux, France) in a concentration of $0.5 \mathrm{mg} / \mathrm{mL}$ was used as a flocculent aid. The $\mathrm{pH}$ during coagulation was 8.5, the same as after the $\mathrm{Fe}^{0} / \mathrm{H}_{2} \mathrm{O}_{2}$ and $\mathrm{Fe}^{2+} / \mathrm{H}_{2} \mathrm{O}_{2}$ processes. The samples were stirred on a magnetic stirrer (Heidolph MR3000, Schwabach, Germany) for 5 min on fast (500 rpm), followed by $10 \mathrm{~min}$ on slow (50 rpm) stirring.

\subsection{Analytical Methods}

The heavy metals were determined according to the PN-EN ISO 11885:2009 standard with ICP-OES Optima 8300 with an ESI-SC (Quartz C2 Dual CyclonicSpray chamber and nebulizer Meinhard type K1 with an ESI-SC Model SC-2DXS autosampler (Perkin Elmer, Waltham, MA, USA)), after microwave mineralization with TITAN MPS (Perkin Elmer, Waltham, MA, USA). The samples were acidified with $\mathrm{HNO}_{3}$ (Merck, Darmstadt, Germany) to a $\mathrm{pH}$ of $<1.0$.

Ions and boron concentrations were determined according to the PN-EN ISO 10304-1:2009 standard with IC (Dionex ICS-5000+, Sunnyvale, CA, USA). Chromatographic column C18 andisocratic elution $36 \mathrm{mmol} \mathrm{KOH}$ (Merck, Darmstadt, Germany) were used as the mobile phase. The samples were filtered through the filter sized $0.45 \mu \mathrm{m}$ and $100 \times$ diluted.

TOC was determined according to the EN 1484:1999 standard with a TOC-L analyzer with an ASI-L autosampler (Shimadzu, Kioto, Japan). The combustion temperature was set to $680^{\circ} \mathrm{C}$.

Because of high chloride content, COD could not be determined with an ISO 6060 standard. An alternative DIN 38409-41:1980-12 standard, designed for matrixes with high chloride content, was selected.

Conductivity was determined with WTW (WTW, Weilheim, Germany) Cond 340i with an electrode TeraCon 325 according to the PN-EN 27888:1999 standard, while pH was determined with pH meter WTW 3310 (WTW, Weilheim, Germany) (an electrodeSenTix 41) according to the PN-EN ISO 10523:2012 standard.

\subsection{Statystical Analysis}

Statistical analyses including a two-way factorial analysis of variance (ANOVA) was performed using R 3.5.1. Statistical Software [34]. In particular, appropriate two-dimensional contour plots were produced to understand and visualize the main effects and two-way interactions occurring during the series of laboratory analysis.

\section{Results and Discussion}

\subsection{Raw Wastewater and Sedimentation}

The parameters of wastewater are shown in Table 1. The effluent was turbid, with a high content of suspended solids (TSS) which were mainly easily settleable solids (ESS). The wastewater was characterized by significant salinity, a high content of sulfate and chlorides, an intensive milky orange color, and turbidity. This was comparable to values and parameters described in the literature $[3,9,10]$.

Due to the large amount of ESS, sedimentation was effective in the FGD wastewater treatment. This process allowed the complete removal of suspensions (gypsum) and color.

Sedimentation accounted for at least part of the heavy metal removal. In case of $\mathrm{Cr}, \mathrm{Cu}, \mathrm{V}$, and $\mathrm{Pb}$, the removal was almost complete to $0.026,0.059,0.042$, and $0.016 \mathrm{mg} / \mathrm{L}$, respectively. However, for the other heavy metals, such as $\mathrm{Zn}, \mathrm{Ag}$, and Ni, the removal rate was low. For Cd, no removal was observed. 
Unfortunately, sedimentation does not allow for any removal of boron. The concentration of boron in wastewater after sedimentation was $336 \mathrm{mg} / \mathrm{L}$, in comparison to $340 \mathrm{mg} / \mathrm{L}$ for raw wastewater.

As a result of sedimentation, COD and TOC decreased to 301 and $43.57 \mathrm{mg} / \mathrm{L}(23.8$ and $8.7 \%$ removal), respectively. In the case of FGD, wastewater COD is a parameter that is difficult to determine. It is related to a significant amount of chlorides dissolved in wastewater. Because of the chlorides' high concentration in FGD, which is far higher than $1000 \mathrm{mg} / \mathrm{L}$ and exceeds the maximum level for the typical COD ISO 6060 determination method, an alternative DIN 38409-41:1980-12 standard was used. Based on the TOC/COD ratio of 0.12 and knowledge of wastewater origin, it is clear that most of the COD is related to inorganic compounds. Because of this, COD should not be recommended as a parameter to assess the quality of FGD wastewater in terms of organic compound content and should be withdrawn from all legal regulations related to FGD wastewater.

\subsection{Heavy Metals Removal}

The results of coagulation are shown in Table 2 and Table S1, while the results of heavy metal removal in $\mathrm{Fe}^{2+} / \mathrm{H}_{2} \mathrm{O}_{2}$ and $\mathrm{Fe}^{0} / \mathrm{H}_{2} \mathrm{O}_{2}$ processes are shown in Table 3, Tables S2 and S3.

Table 2. FGD wastewater coagulation treatment results. $\mathrm{FeCl}_{3}$ dose (mg/L), $\mathrm{pH}=8.5, \mathrm{COD}, \mathrm{TOC}, \mathrm{B}$, and heavy metals $(\mathrm{mg} / \mathrm{L})$.

\begin{tabular}{cccccccccccccc}
\hline & $\mathbf{F e C l}_{\mathbf{3}}$ & $\mathbf{C O D}$ & $\mathbf{T O C}$ & $\mathbf{B}$ & $\mathbf{A g}$ & $\mathbf{C d}$ & $\mathbf{C r}$ & $\mathbf{C u}$ & $\mathbf{F e}$ & $\mathbf{N i}$ & $\mathbf{P b}$ & $\mathbf{V}$ & $\mathbf{Z n}$ \\
\hline Raw & 50 & 254 & 43.48 & 334 & 0.010 & 0.236 & 0.012 & 0.008 & 4.131 & 0.617 & 0.011 & $<0.005$ & 1.133 \\
Raw & 75 & 254 & 44.01 & 334 & 0.036 & 0.165 & 0.020 & 0.021 & 1.986 & 0.479 & $<0.010$ & $<0.005$ & 0.422 \\
Raw & 100 & 264 & 43.51 & 329 & 0.036 & 0.152 & 0.020 & 0.025 & 1.487 & 0.470 & $<0.010$ & $<0.005$ & 0.320 \\
Raw & 125 & 258 & 43.00 & 328 & 0.036 & 0.126 & 0.022 & 0.022 & 1.807 & 0.388 & $<0.010$ & $<0.005$ & 0.285 \\
Raw & 150 & 260 & 43.99 & 327 & 0.034 & 0.117 & 0.022 & 0.019 & 1.414 & 0.373 & $<0.010$ & $<0.005$ & 0.167 \\
Raw & 175 & 260 & 43.76 & 327 & 0.036 & 0.103 & 0.021 & 0.019 & 0.986 & 0.342 & $<0.010$ & $<0.005$ & 0.138 \\
Sedimented & 50 & 260 & 42.11 & 337 & 0.033 & 0.177 & 0.025 & 0.030 & 3.041 & 0.480 & $<0.010$ & 0.019 & 0.330 \\
Sedimented & 75 & 262 & 40.93 & 338 & 0.030 & 0.154 & 0.021 & 0.024 & 2.424 & 0.401 & $<0.010$ & 0.015 & 0.184 \\
Sedimented & 100 & 270 & 41.85 & 337 & 0.033 & 0.142 & 0.026 & 0.025 & 2.668 & 0.378 & $<0.010$ & 0.014 & 0.180 \\
Sedimented & 125 & 266 & 41.34 & 334 & 0.033 & 0.125 & 0.025 & 0.026 & 2.877 & 0.329 & 0.016 & 0.015 & 0.170 \\
Sedimented & 150 & 272 & 42.04 & 326 & 0.038 & 0.138 & 0.034 & 0.036 & 3.037 & 0.322 & 0.019 & 0.013 & 0.389 \\
Sedimented & 175 & 266 & 41.78 & 331 & 0.032 & 0.121 & 0.023 & 0.023 & 4.208 & 0.341 & 0.018 & 0.020 & 0.226 \\
\hline
\end{tabular}

Table 3. Heavy metals concentration after $\mathrm{Fe}^{2+} / \mathrm{H}_{2} \mathrm{O}_{2}$ process without sedimentation.

\begin{tabular}{cccccccccccc}
\hline $\mathbf{F e}^{\mathbf{2 +}}$ & $\mathbf{H}_{\mathbf{2}} \mathbf{O}_{\mathbf{2}}$ & $\mathbf{T i m e}$ & $\mathbf{A g}$ & $\mathbf{C d}$ & $\mathbf{C u}$ & $\mathbf{C r}$ & $\mathbf{N i}$ & $\mathbf{P b}$ & $\mathbf{V}$ & $\mathbf{Z n}$ & $\mathbf{F e}$ \\
\hline $\mathbf{m g} / \mathbf{L})$ & $\mathbf{( m g} / \mathbf{L})$ & $\mathbf{( m i n )}$ & & & & & $\mathbf{( m g} / \mathbf{L})$ & & & & \\
\hline 150 & 300 & 5 & 0.020 & 0.105 & 0.006 & 0.031 & 0.167 & $<0.010$ & 0.058 & 0.028 & 0.182 \\
150 & 300 & 15 & 0.012 & 0.086 & $<0.005$ & 0.033 & 0.126 & $<0.010$ & 0.061 & 0.028 & 0.198 \\
150 & 300 & 30 & 0.015 & 0.097 & $<0.005$ & 0.032 & 0.201 & $<0.010$ & 0.063 & 0.019 & 0.175 \\
150 & 300 & 60 & 0.018 & 0.110 & $<0.005$ & 0.031 & 0.214 & $<0.010$ & 0.070 & 0.025 & 0.156 \\
150 & 600 & 5 & 0.026 & 0.101 & 0.007 & 0.027 & 0.218 & $<0.010$ & 0.075 & 0.046 & 0.199 \\
150 & 600 & 15 & 0.019 & 0.085 & 0.005 & 0.036 & 0.154 & $<0.010$ & 0.061 & 0.033 & 0.216 \\
150 & 600 & 30 & 0.018 & 0.111 & $<0.005$ & 0.037 & 0.262 & $<0.010$ & 0.073 & 0.030 & 0.215 \\
150 & 1200 & 5 & 0.027 & 0.072 & $<0.005$ & 0.017 & 0.240 & $<0.010$ & 0.075 & 0.040 & 0.209 \\
150 & 1200 & 15 & 0.024 & 0.055 & $<0.005$ & 0.020 & 0.133 & $<0.010$ & 0.050 & 0.032 & 0.179 \\
150 & 1200 & 30 & 0.028 & 0.081 & $<0.005$ & 0.020 & 0.241 & $<0.010$ & 0.051 & 0.044 & 0.161 \\
150 & 1200 & 60 & 0.024 & 0.072 & $<0.005$ & 0.018 & 0.244 & $<0.010$ & 0.056 & 0.034 & 0.584 \\
\hline
\end{tabular}

The BAT recommended coagulation did not improve the effect of sedimentation, and the concentrations of selected heavy metals were similar. The only benefit is the increased sedimentation rate. A similar effect was obtained for flocculent aid, whether it was AN913SH or the one used in the power plant. No additional heavy metals removal was obtained, only the sedimentation rate was increased. A combined usage of coagulant and polyelectrolyte allows for sedimentation in less than $1 \mathrm{~min}$, which is very important from a technological perspective. TMT-15 was used in order 
to remove heavy metals. However, the efficiency of the chelating agent in respect to most of heavy metals was negligible. Only in the case of cadmium was the concentration significantly decreased (about 90\%). Similarly, but with a much smaller effect, about 50\% removal was obtained for copper, but the concentration was ten times lower than that of cadmium.

In contrast to the coagulation process, oxidation allowed for very effective heavy metal removal. This was even more effective than the simultaneous use of the coagulant, polyelectrolyte, and TMT-15 (Table S1 versus Tables S2 and S3). It is clear for Cu that, after both the homogenousand heterogeneous Fenton process, the concentration was usually below the detection limit. This was the same case for $\mathrm{Pb}$. Important removals are also obtained for $\mathrm{Ni}$ and $\mathrm{Zn}$. In these cases, the metal efficiency of TMT-15 was low. The opposite effect was obtained in the case of $\mathrm{Cr}$. As a result of oxidation, $\mathrm{Cr}$ (III) forms undergo oxidation to $\mathrm{Cr}$ (VI). $\mathrm{Cr}$ (VI) specifically possesses a higher solubility than $\mathrm{Cr}(\mathrm{III})$ and, as a result, the total $\mathrm{Cr}$ concentration after oxidation processes is slightly higher than in the case of coagulation. Iron, used both in the oxidation processes and in coagulation, is better removed inoxidation. In comparing oxidation processes, greater heavy metal removal was obtained with the $\mathrm{Fe}^{2+} / \mathrm{H}_{2} \mathrm{O}_{2}$ process. It can be concluded that total heavy metal removal is greater during oxidation processes.

\subsection{Boron Removal}

The results of boron removal in coagulation, $\mathrm{Fe}^{2+} / \mathrm{H}_{2} \mathrm{O}$, and $\mathrm{Fe}^{0} / \mathrm{H}_{2} \mathrm{O}_{2}$ processes are shown in Tables 2, 4 and 5, and Table S1.

Maximum boron removal was obtained from the $\mathrm{Fe}^{2+} / \mathrm{H}_{2} \mathrm{O}_{2}$ process on sedimented wastewater and $150 / 300 \mathrm{mg} / \mathrm{L} \mathrm{Fe}^{2+} / \mathrm{H}_{2} \mathrm{O}_{2}$ reagent doses. B concentration was decreased to $212 \mathrm{mg} / \mathrm{L}$ (37.6\% total removal, from an initial value of $340 \mathrm{mg} / \mathrm{L}$ ). A similar effect was obtained for the same iron dose and a higher $600 \mathrm{mg} / \mathrm{L} \mathrm{H}_{2} \mathrm{O}_{2}$ dose. For all other doses and process times, lesser effects were obtained. The results obtained for the $\mathrm{Fe}^{0} / \mathrm{H}_{2} \mathrm{O}_{2}$ process were worse than the $\mathrm{Fe}^{2+} / \mathrm{H}_{2} \mathrm{O}_{2}$ process. Interestingly, the results obtained for raw wastewater were better than those for the sedimented wastewater. The usage of coagulation with flocculent was a less effective process for boron removal. Even flocculent and TMT-15 usage did not allow for high boron removal. It is also important to note that boron removal efficiency is very sensitive in relation to the coagulant dose. A small change in the dose results in a significant deterioration in the boron removal rate. The results obtained in this study can be compared with the results obtained by Marcinowski et al. [35]. FGD wastewater was subjected to Al-based coagulation treatment, and obtained boron removal was up to $75.3 \%$. As it is usually accepted for Al coagulation, the important removal mechanism is sorption. For Fe-based coagulants, the intensity of sorption is lower. This corresponds with the lower B removal rate for both coagulation and oxidation processes. However, this hypothesis requires confirmation through further research.

Table 4. FGD wastewater $\mathrm{Fe}^{2+} / \mathrm{H}_{2} \mathrm{O}_{2}$ process treatment results, time $=60 \mathrm{~min}$.

\begin{tabular}{ccccccccccccc}
\hline Sediment & - & - & - & + & + & + & + & + & + & + & + & + \\
\hline $\mathrm{Fe}^{2+}(\mathrm{mg} / \mathrm{L})$ & 150 & 150 & 150 & 75 & 75 & 75 & 150 & 150 & 150 & 300 & 300 & 300 \\
$\mathrm{H}_{2} \mathrm{O}_{2}$ & 300 & 600 & 1200 & 150 & 300 & 600 & 300 & 600 & 1200 & 600 & 1200 & 2400 \\
$(\mathrm{mg} / \mathrm{L})$ & 307 & 300 & 300 & 319 & 315 & 314 & 212 & 228 & 302 & 291 & 281 & 288 \\
$\mathrm{~B}(\mathrm{mg} / \mathrm{L})$ & 300 \\
\hline
\end{tabular}

Table 5. FGD wastewater $\mathrm{Fe}^{0} / \mathrm{H}_{2} \mathrm{O}_{2}$ process treatment results, time $=60 \mathrm{~min}$.

\begin{tabular}{ccccccccccccccc}
\hline Sediment & - & - & - & - & - & - & - & - & - & - & - & - & + & + \\
\hline $\mathrm{Fe}^{0}(\mathrm{~g} / \mathrm{L})$ & 1 & 1 & 1 & 2 & 2 & 2 & 4 & 4 & 4 & 8 & 8 & 8 & 1 & 1 \\
$\mathrm{H}_{2} \mathrm{O}_{2}$ & 300 & 600 & 1200 & 300 & 600 & 1200 & 300 & 600 & 1200 & 300 & 600 & 1200 & 300 & 600 \\
$(\mathrm{mg} / \mathrm{L})$ & 294 & 308 & 317 & 335 & 327 & 321 & 325 & 312 & 319 & 288 & 310 & 290 & 320 & 352 \\
$\mathrm{~B}(\mathrm{mg} / \mathrm{L})$ & 294 &
\end{tabular}




\subsection{TOC and COD Removal}

The results of coagulation are shown in Table 2 and Table S1. The exemplary TOC and COD removal plots in $\mathrm{Fe}^{2+} / \mathrm{H}_{2} \mathrm{O}_{2}$ and $\mathrm{Fe}^{0} / \mathrm{H}_{2} \mathrm{O}_{2}$ processes are shown in Figures 1-3.

As expected, both $\mathrm{Fe}^{0} / \mathrm{H}_{2} \mathrm{O}_{2}$ and $\mathrm{Fe}^{2+} / \mathrm{H}_{2} \mathrm{O}_{2}$ processes conducted on both raw and sedimented wastewater allowed for COD and TOC removal. Whether initial sedimentation was used or not, as well as $\mathrm{Fe}^{2+}, \mathrm{Fe}^{0}$ and $\mathrm{H}_{2} \mathrm{O}_{2}$ doses, a rapid decrease in TOC and COD was observed after the shortest process time. COD decreased to $240-270 \mathrm{mg} / \mathrm{L}$ and TOC to $38-40 \mathrm{mg} / \mathrm{L}$ from an initial 395 and $47.81 \mathrm{mg} / \mathrm{L}$, respectively. For longer process times, almost no additional removal was observed. From the technological point of view, it is then not recommended to extend the process time to more than 5-15 min for COD and TOC removal. Treatment effect is related to chemical oxidation, coagulation, and precipitation/sedimentation. Coagulation (Table 2 and Table S1) provides similar COD removal to $250-270 \mathrm{mg} / \mathrm{L}$ but a slightly worse TOC removal to $41-44 \mathrm{mg} / \mathrm{L}$. A poor (0.51) COD/TOC removal correlation in coagulation proves that COD is related to inorganic compounds. It could be compared with the COD/TOC removal correlation for the $\mathrm{Fe}^{2+} / \mathrm{H}_{2} \mathrm{O}_{2}$ and $\mathrm{Fe}^{0} / \mathrm{H}_{2} \mathrm{O}_{2}$ processes (0.90). It confirms the effectiveness of radical oxidation of inorganic, sulfur-based, reduced compounds. After both oxidation processes, regardless of using initial sedimentation, the concentration of sulfates(IV) is much higher (data not shown) than in raw wastewater.

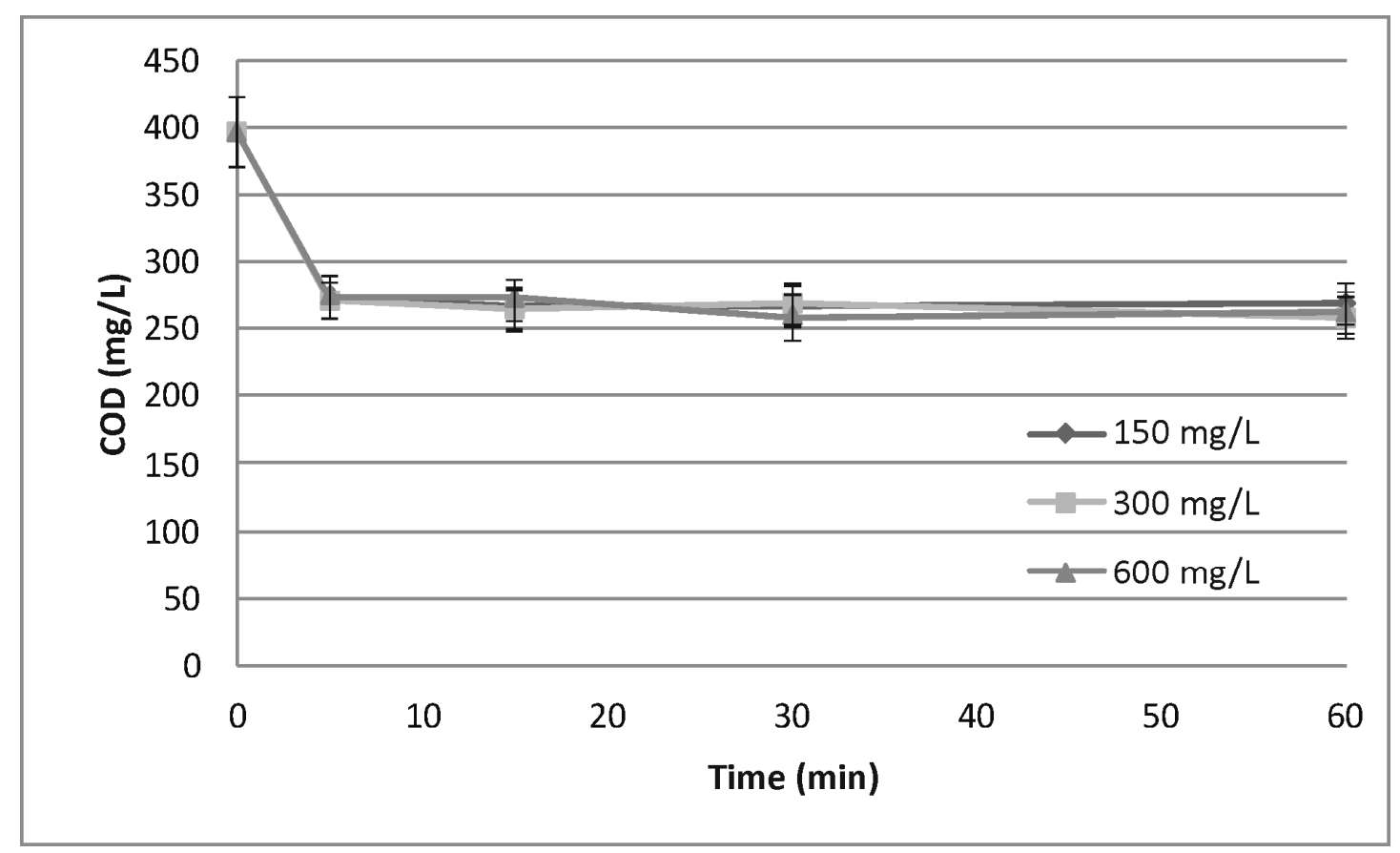

Figure 1. COD (chemical oxygen demand) removal in Fenton process: $\mathrm{Fe}^{2+}$ dose 75 (mg/L), sedimented wastewater. 


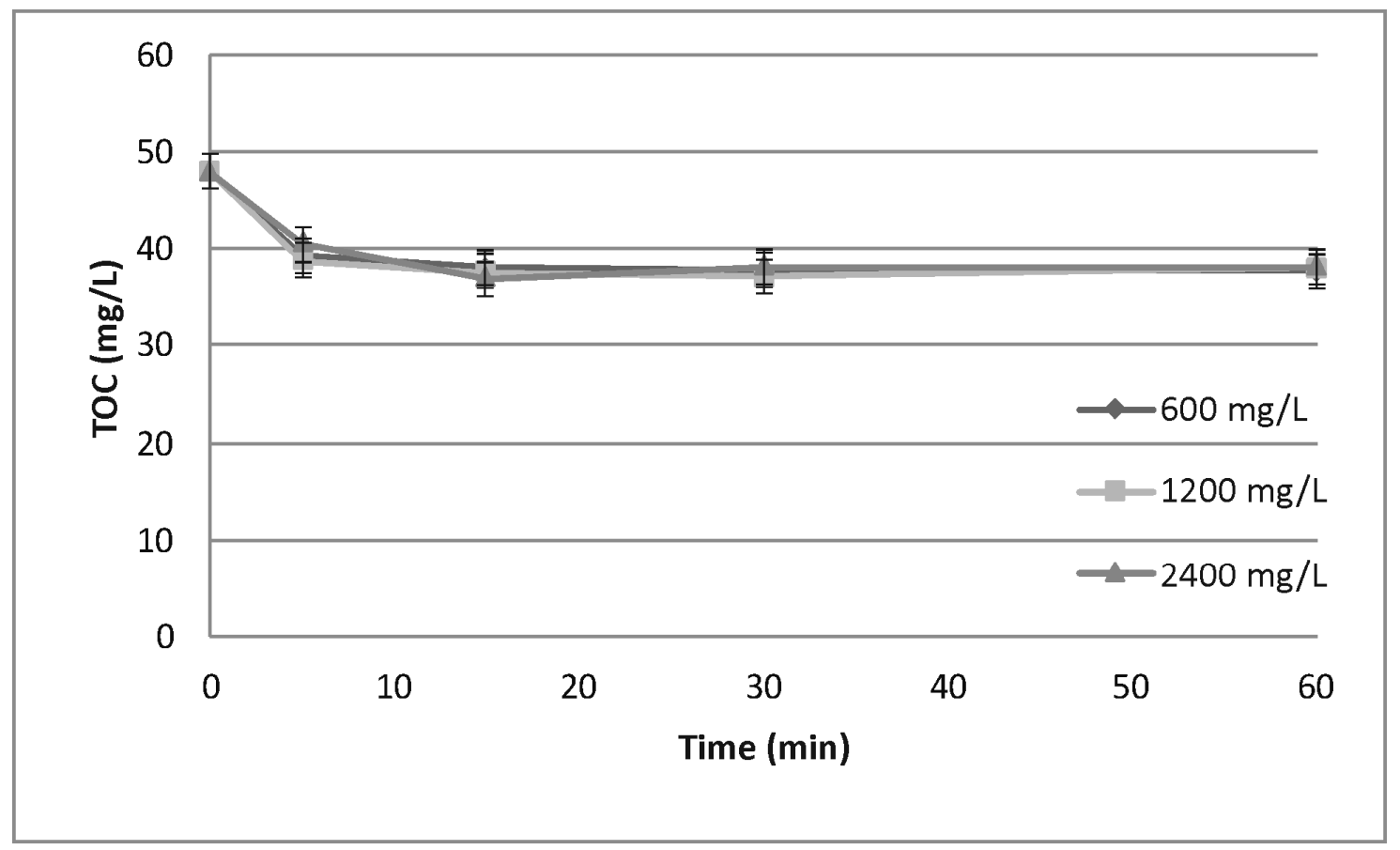

Figure 2. TOC (total organic carbon) removal in Fenton process: $\mathrm{Fe}^{2+}$ dose $300(\mathrm{mg} / \mathrm{L})$, sedimented wastewater.

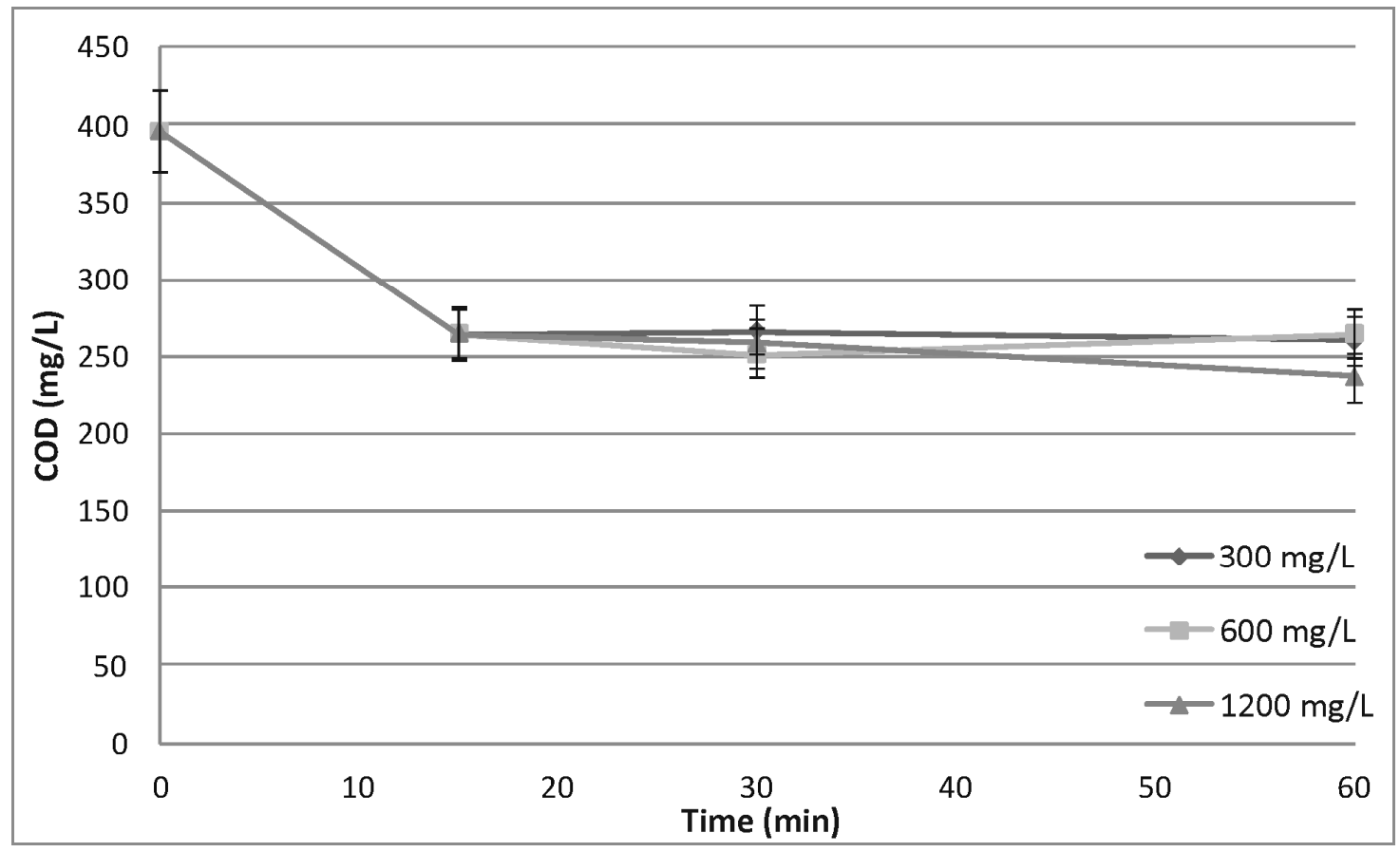

Figure 3. $\mathrm{COD}$ removal in $\mathrm{Fe}^{0} / \mathrm{H}_{2} \mathrm{O}_{2}$ process: $\mathrm{Fe}^{0}$ dose 8 (g/L), raw wastewater.

\subsection{Statistical Analysis}

The numerical results of the two-way factorial analysis of variance (ANOVA) explain how the iron type $\left(\mathrm{Fe}^{0}\right.$ and $\left.\mathrm{Fe}^{2+}\right)$ influenced COD and TOC. The results of the analysis are presented in Tables 6 and 7. Graphic results showing the main effects and two-way interactions for TOC (i.e., TOC versus $\mathrm{Fe}^{0}$ and $\mathrm{H}_{2} \mathrm{O}_{2}$ and TOC versus $\mathrm{Fe}^{2+}$ and $\mathrm{H}_{2} \mathrm{O}_{2}$ ) are presented in Figures S1-S4. 
Table 6. ANOVA (analysis of variance) results for TOC and $\mathrm{Fe}^{2+} / \mathrm{Fe}^{0}$, time 60 (min) vs. all process times.

\begin{tabular}{|c|c|c|c|c|}
\hline & F Value, $\mathrm{Fe}^{2+}$ & $\operatorname{Pr}(<\mathrm{F}), \mathrm{Fe}^{2+}$ & F Value, $\mathrm{Fe}^{0}$ & $\operatorname{Pr}(<F), F^{0}$ \\
\hline & 60/All & 60/All & 60/All & 60/All \\
\hline $\mathrm{Fe}^{0}$ & $17.131 / 30.485$ & $0.00326 / 1.7 \times 10^{-6}$ & $7.772 / 21.320$ & $0.0211 / 4.81 \times 10^{-5}$ \\
\hline $\mathrm{H}_{2} \mathrm{O}_{2}$ & $2.513 / 8.139$ & $0.15158 / 0.00658$ & $0.952 / 1.602$ & $0.3546 / 0.214$ \\
\hline $\mathrm{Fe}^{0}: \mathrm{H}_{2} \mathrm{O}_{2}$ & $0.054 / 2.663$ & $0.82177 / 0.10983$ & $0.553 / 0.608$ & $0.4760 / 0.441$ \\
\hline
\end{tabular}

Table 7. ANOVA results for COD and $\mathrm{Fe}^{2+} / \mathrm{Fe}^{0}$, time 60 (min) vs. all process times.

\begin{tabular}{ccccc}
\hline & ${\text { F Value, } \mathbf{F e}^{2+}}$ & $\operatorname{Pr}(<\mathrm{F}), \mathrm{Fe}^{2+}$ & F Value, $^{2+} \mathbf{F}^{\mathbf{0}}$ & $\left.\operatorname{Pr}^{2}<\mathrm{F}\right), \mathrm{Fe}^{\mathbf{0}}$ \\
\cline { 2 - 5 } & 60/All & 60/All & 60/All & 60/All \\
\hline $\mathrm{Fe}^{0}$ & $1.279 / 22.132$ & $0.291 / 2.54 \times 10^{-5}$ & $7.201 / 9.051$ & $0.0251 / 0.00477$ \\
$\mathrm{H}_{2} \mathrm{O}_{2}$ & $0.199 / 1.942$ & $0.667 / 0.170$ & $0.108 / 0.916$ & $0.7504 / 0.34481$ \\
$\mathrm{Fe}^{0}: \mathrm{H}_{2} \mathrm{O}_{2}$ & $1.605 / 5.161$ & $0.241 / 0.028$ & $1.889 / 1.907$ & $0.2026 / 0.17576$ \\
\hline
\end{tabular}

It was found that the influence of iron $\left(\mathrm{Fe}^{0}\right.$ or $\left.\mathrm{Fe}^{2+}\right)$ was statistically significant at the confidence level of 0.05 , except in one case where $\mathrm{COD}, \mathrm{Fe}^{2+}$, and time $=60$ (min). However, this significance was not observed systematically when using $\mathrm{H}_{2} \mathrm{O}_{2}$. The effects of the $\mathrm{H}_{2} \mathrm{O}_{2}-\mathrm{Fe}$ interaction were observed only in the case of TOC and $\mathrm{Fe}^{2+}$ for a time of $60 \mathrm{~min}$. An analysis of the figures for COD, TOC, and the two-factor ANOVA plots (Figures S1-S4) also confirms that the $\mathrm{Fe}^{0} / \mathrm{Fe}^{2+}$ application on COD and TOC had a higher impact than the $\mathrm{H}_{2} \mathrm{O}_{2}$ application.

\section{Conclusions}

FGD wastewater can be effectively treated with all three investigated processes: coagulation with Fe-based coagulants, the $\mathrm{Fe}^{0} / \mathrm{H}_{2} \mathrm{O}_{2}$ process, and the $\mathrm{Fe}^{2+} / \mathrm{H}_{2} \mathrm{O}_{2}$ process. These processes can be ranked in terms of the efficiency of pollutants (heavy metals, TOC, and COD) removal: $\mathrm{Fe}^{2+} / \mathrm{H}_{2} \mathrm{O}_{2}>$ $\mathrm{Fe}^{0} / \mathrm{H}_{2} \mathrm{O}_{2} \gg$ coagulation. Oxidation processes allowed for almost complete heavy metal removal. It could then be possible not to use toxic chelating agent TMT-15 during FGD wastewater treatment. The most likely effect is related to sorption on the created hydroxide surface and co-precipitation. Future research will include the investigation of the efficiency of sorption using various sorbents as the final FGD treatment step.

ANOVA was applied to determine the significance of the two independent variables and their interactions. Statistical analysis confirms the high efficiency and applicability of the treatment process.

Both oxidation processes used, homogenous and heterogeneous Fenton, meet the technical FGD wastewater treatment requirements of the BAT for large combustion sources. Therefore, the homogenous and heterogeneous Fenton processes can be viable alternatives for the wet lime method FGD wastewater treatment in contrast to the BAT recommended iron-based coagulation.

In the course of future research, it is planned to assess the effectiveness of the investigated oxidation processes on an industrial scale.

Supplementary Materials: The following are available online at http:/ /www.mdpi.com/2227-9717/6/11/229/s1, Figure S1. Main effects and 2-way interactions for TOC, for $\mathrm{Fe}^{0}$ and all process times. Figure S2. Main effects and 2-way interactions for TOC, for $\mathrm{Fe}^{0}$ and time $60 \mathrm{~min}$. Figure S3. Main effects and 2-way interactions for TOC, for $\mathrm{Fe}^{2+}$ and all process times. Figure S4. Main effects and 2-way interactions for TOC, for $\mathrm{Fe}^{2+}$ and time $60 \mathrm{~min}$. Table S1. FGD wastewater coagulation treatment results. $\mathrm{FeCl}_{3}$ dose $(100 \mathrm{mg} / \mathrm{L}), \mathrm{pH}=8.5$, TMT dose $(\mu \mathrm{L} / \mathrm{L})$, Flocculent dose (mg/L), A = AN913SH, FGD = polymer used in power plant, COD, TOC, B and heavy metals (mg/L). Table S2. Heavy metals concentration after $\mathrm{Fe}^{2+} / \mathrm{H}_{2} \mathrm{O}_{2}$ process after sedimentation. Table S3. Heavy metals concentration after $\mathrm{Fe}^{0} / \mathrm{H}_{2} \mathrm{O}_{2}$ process.

Author Contributions: The authors contribution is as follows: conceptualization and methodology: J.B. and P.M.; laboratory work: J.B., P.M., M.M., S.S.; statistical analysis: J.Z.; writing and original draft preparation: all authors. Each author contribution is equal at $20 \%$.

Funding: This research received no external funding. 
Conflicts of Interest: The authors declare no conflicts of interest.

\section{References}

1. Feng, C.; Gao, X.; Tang, Y.; Zhang, Y. Comparative life cycle environmental assessment of flue gas desulphurization technologies in China. J. Clean. Prod. 2014, 68, 81-92. [CrossRef]

2. Zhang, Y.; Guo, S.; Zhou, J.; Li, C.; Wang, G. Flue gas desulfurization by $\mathrm{FeSO}_{4}$ solutions and coagulation performance of the polymeric ferric sulfate by-product. Chem. Eng. Process. 2010, 49, 859-865. [CrossRef]

3. Córdoba, P. Status of Flue Gas Desulphurisation (FGD) systems from coal-fired power plants: Overview of the physic-chemical control processes of wet limestone FGDs. Fuel 2015, 144, 274-286. [CrossRef]

4. Tan, E.; Ünal, S.; Doğan, A.; Letournel, E.; Pellizzari, F. New “wet type" electron beam flue gas treatment pilot plant. Radiat. Phys. Chem. 2016, 119, 109-115. [CrossRef]

5. Jiang, F.; Zhang, L.; Peng, G.-L.; Liang, S.-Y.; Qian, J.; Wei, L.; Chen, G.-H. A novel approach to realize SANI process in freshwater sewage treatment-Use of wet flue gas desulfurization waste streams as sulfur source. Water Res. 2013, 47, 5773-5782. [CrossRef] [PubMed]

6. Huang, Y.; Peddi, P.; Tang, C.; Zeng, H.; Teng, X. Hybrid zero-valent iron process for removing heavy metals and nitrate from flue-gas-desulfurization wastewater. Sep. Purif. Technol. 2013, 118, 690-698. [CrossRef]

7. Del Valle-Zermeño, R.; Formosa, J.; Aparicio, J.A.; Guembe, M.; Chimenos, J.M. Transposition of wet flue gas desulfurization using $\mathrm{MgO}$ by-products: From laboratory discontinuous batch reactor to pilot scrubber. Fuel Process. Technol. 2015, 138, 30-36. [CrossRef]

8. Zhu, J.; Ye, S.-C.; Bai, J.; Wu, Z.-Y.; Liu, Z.-H.; Yang, Y.-F. A concise algorithm for calculating absorption height in spray tower for wet limestone-gypsum flue gas desulfurization. Fuel Process. Technol. 2015, 129, 15-23. [CrossRef]

9. Trojanowska, J.; Litwinowicz, A. Possibility of heavy metal precipitationon various sludge treatment stages of a wet flue gas desulfurization process. Biuletyn Energetyka 2013, 6, 27-32.

10. Litwinowicz, A. Wet FGD installation wastewater treatment plant. Biuletyn Energetyka 2011, 2, 360-363.

11. Song, J. Study on coagulation treatment of desulfurization wastewater of coal-fired power plants. J. Chem. Pharm. Res. 2013, 5, 782-788.

12. Panepinto, D.; Fiore, S.; Genon, G.; Acri, M. Thermal valorization of sewer sludge: Pespectives for large wastewater treatment plants. J. Clean. Prod. 2016, 137, 1323-1329. [CrossRef]

13. Schuetze, J.; Kunth, D.; Weissbach, S.; Koeser, H. Mercury vapor pressure of flue gas desulfurization scrubber suspensions: Effects of pH level, gypsum, and iron. Environ. Sci. Technol. 2012, 46, 3008-3013. [CrossRef] [PubMed]

14. Yan, Y.; Li, Q.; Sun, X.; Ren, Z.; He, F.; Wang, Y.; Wang, L. Recycling flue gas desulphurization (FGD) gypsum for removal of $\mathrm{Pb}(\mathrm{II})$ and $\mathrm{Cd}(\mathrm{II})$ from wastewater. J. Colloid Interface Sci. 2015, 457, 86-95. [CrossRef] [PubMed]

15. Zhao, Y.; Han, Y.; Ma, T.; Guo, T. Simultaneous desulfurization and denitrification from flue gas by Ferrate(VI). Environ. Sci. Technol. 2011, 45, 4060-4065. [CrossRef] [PubMed]

16. Bogacki, J.; Marcinowski, P.; Zawadzki, J.; Majewski, M.; Sivakumar, S. Oczyszczanieścieków z instalacjiodsiarczaniaspalin z wykorzystaniem $\mathrm{Fe}^{0} / \mathrm{H}_{2} \mathrm{O}_{2}$. Przem. Chem. 2017, 96, 2486-2490. [CrossRef]

17. Guan, B.; Ni, W.; Wu, Z.; Lai, Y. Removal of $\mathrm{Mn}(\mathrm{II})$ and $\mathrm{Zn}(\mathrm{II})$ ions from flue gas desulfurization wastewater with water-soluble chitosan. Sep. Purif. Technol. 2009, 65, 269-274. [CrossRef]

18. Commission Implementing Decision (EU) 2017/1442 of 31 July 2017 Establishing Best Available Techniques (BAT) Conclusions, under Directive 2010/75/EU of the European Parliament and of the Council, for Large Combustion Plants (Notified under Document C(2017) 5225). Available online: https: / / eur-lex.europa.eu/ legal-content/EN/TXT/?uri=CELEX:32017D1442 (accessed on 6 June 2018).

19. Babuponnusami, A.; Muthukumar, K. A review on Fenton and improvements to the Fenton process for wastewater treatment. J. Environ. Chem. Eng. 2014, 2, 557-572. [CrossRef]

20. Bautitz, I.R.; Velosa, A.C.; Nogueira, R.F.P. Zero valent iron mediated degradation of the pharmaceutical diazepam. Chemosphere 2012, 88, 688-692. [CrossRef] [PubMed]

21. Segura, Y.; Martínez, F.; Melero, J.A. Effective pharmaceutical wastewater degradation by Fenton oxidation with zero-valent iron. Appl. Catal. B Environ. 2013, 136-137, 64-69. [CrossRef] 
22. Barreto-Rodrigues, M.; Silva, F.T.; Paiva, T.C.B. Optimization of Brazilian TNT industry wastewater treatment using combined zero-valent iron and fenton processes. J. Hazard. Mater. 2009, 168, 1065-1069. [CrossRef] [PubMed]

23. Kim, D.; Kim, J.; Choi, W. Effect of magnetic field on the zero valent iron induced oxidation reaction. J. Hazard. Mater. 2011, 192, 928-931. [CrossRef] [PubMed]

24. Shimizu, A.; Tokumura, M.; Nakajima, K.; Kawase, Y. Phenol removal using zero-valent iron powder in the presence of dissolved oxygen: Roles of decomposition by the Fenton reaction and adsorption/precipitation. J. Hazard. Mater. 2012, 201-202, 60-67. [CrossRef] [PubMed]

25. Fjordbøge, A.S.; Baun, A.; Vastrup, T.; Kjeldsen, P. Zero valent iron reduces toxicity and concentrations of organophosphate pesticides in contaminated groundwater. Chemosphere 2013, 90, 627-633. [CrossRef] [PubMed]

26. Xi, Y.; Sun, Z.; Hreid, T.; Ayoko, G.A.; Frost, R.L. Bisphenol A degradation enhanced by Air bubbles via advanced oxidation using in situ generated ferrous ions from nano zero-valent iron/palygorskite composite materials. Chem. Eng. J. 2014, 247, 66-74. [CrossRef]

27. Martins, R.C.; Lopes, D.V.; Quina, M.J.; Quinta-Ferreira, R.M. Treatment improvement of urban landfill leachates by Fenton-like process using ZVI. Chem. Eng. J. 2012, 192, 219-225. [CrossRef]

28. Lai, P.; Zhao, H.; Wang, C.; Ni, J. Advanced treatment of coking wastewater by coagulation and zero-valent iron processes. J. Hazard. Mater. 2007, 147, 232-239. [CrossRef] [PubMed]

29. Taha, M.R.; Ibrahim, A.H. Characterization of nano zero-valent iron (nZVI) and its application in sono-Fenton process to remove COD in palm oil mill effluent. J. Environ. Chem. Eng. 2014, 2, 1-8. [CrossRef]

30. Suzuki, T.; Moribe, M.; Oyama, Y.; Niinae, M. Mechanism of nitrate reduction by zero-valent iron: Equilibrium and kinetics studies. Chem. Eng. J. 2012, 183, 271-277. [CrossRef]

31. Pourrezaei, P.; Alpatova, A.; Khosravi, K.; Drzewicz, P.; Chen, Y.; Chelme-Ayala, P.; El-Din, M.G. Removal of organic compounds and trace metals from oil sands process-affected water using zero valent iron enhanced by petroleum coke. J. Environ. Manag. 2014, 139, 50-58. [CrossRef] [PubMed]

32. Martins, R.C.; Nunesa, M.; Gando-Ferreira, L.M.; Quinta-Ferreira, R.M. Nanofiltration and Fenton's process over iron shavings for surfactants removal. Environ. Technol. 2014, 35, 2380-2388. [CrossRef] [PubMed]

33. Marcinowski, P.; Zapałowska, E.; Maksymiec, J.; Naumczyk, J.; Bogacki, J. Hydraulic fracturing flow-back fluid treatment by $\mathrm{ZVI} / \mathrm{H}_{2} \mathrm{O}_{2}$ process. Desalin. Water Treat. 2018, 129, 177-184. [CrossRef]

34. R Core Team. R: A Language and Environment for Statistical Computing. 2017. Available online: https: / / www.R-project.org/ (accessed on 1 August 2018).

35. Marcinowski, P.; Bogacki, J.; Majewski, M.; Zawadzki, J.; Sivakumar, S. Application of aluminum-based coagulants for improving efficiency of flue gas desulfurization wastewater treatment in coal-fired power plant. Przem. Chem. 2018. under review. 